\title{
DOI 10.26886/2414-634X.3(22)2018.6
}

UDC: $94(477) \ll 19 »$

\section{SOCIO-ECONOMIC PRECONDITIONS FOR THE DEVELOPMENT OF CIVIL SOCIETY OF UKRAINE}

\section{N. Moroz}

National Technical University «Dniprovska Polytechnic», Ukraine, Dnipro

The article analyzes the socio-economic preconditions for the formation of civil society in Ukraine. The events of the history of independent Ukraine are highlighted, which greatly influenced the formation of its institutes of the period of independence. It is substantiated, how exactly legal support has affected the process of institutionalization of civil society. Determined how the state through privatization and privatization, as well as the creation of conditions for a socially oriented market economy, contributed to the formation of a private property institution. The significance of the "Orange Revolution" for the socio-economic development of Ukraine is determined.

Key words: civil society, state, democracy, private property, market economy, law, reforms.

Мороз Н. О. Соціально-економічні передумови становлення громадянського суспільства України/ Національний технічний університет «Дніпровська політехніка», Україна, м. Дніпро

В cmammi проаналізовані соціально-економічні передумови становлення громадянського суспільства в Україні. Висвітлюються події історії незалежної України, які значною мірою вплинули на формування його інститутів періоду незалежності. Обгрунтовано, як саме правове забезпечення позначилось на процесі інституалізації громадянського суспільства. Визначено, як держава шляхом роздержавлення та приватизації, а також створенням умов для соціально орієнтованої ринкової економіки сприяли фрормуванню 
інституту приватної власності. З'ясовано значення «Помаранчевої революції» для соціально-економічного розвитку України.

Ключові слова: громадянське суспільство, держава, демократія, приватна власність, ринкова економіка, закон, реформи.

Вступ. Історичний досвід демонструє, що ефективна розбудова держави, добробут суспільства залежать у першу чергу від розвитку економіки. Протягом тривалого часу Україна перебувала в авторитарній державі 3 плановою командно-адміністративною системою, одержавленою економікою, відсутністю приватної власності та господарської ініціативи конкретних суб'єктів. Значимість економічної сфери суспільства дає привід визначати громадянське суспільство як систему самостійних, відносно незалежних від держави соціально-економічних відносин між юридично вільними і рівноправними людьми - членами суспільства. В умовах проголошення незалежності України й набуття нею внутрішнього і зовнішнього суверенітету, важливим стає з'ясування основних соціальноекономічних передумов становлення громадянського суспільства.

Проблема становлення громадянського суспільства становить коло наукових інтересів багатьох дослідників. А 3 набуттям самостійності нашої держави вона набула ще більшої актуальності і знайшла своє відображення в працях таких вчених як В. Ю. Барков [1], О. С. Головащенко [4], А. Ф. Колодій [7], І. В. Макарова [11], О. М. Нечепоренко [13], Т. В. Розова [15], Ф. Рудич [17] та ін. 3 огляду на значний науковий інтерес представників різних дисциплін (політологів, юристів, фрілософів) проблема громадянського суспільства не знайшла достатнього висвітлення в працях історичного характеру.

Тема нашого дослідження бачиться актуальною, як у теоретичному, так і в практичному аспектах. По-перше, доцільність її 
розробки зумовлена необхідністю комплексного вивчення соціальноекномічних передумов розбудови громадянського суспільства України. По-друге, перебіг цього процесу недостатньо висвітлений сучасними вченими. Можемо пояснити такий стан розробки історії громадянського суспільства політологізованістю цієї проблематики, наближеністю історичних подій до сучасних вчених-істориків.

Метою даного дослідження $€$ з'ясування соціально-економічних умов становлення громадянського суспільства України в історичній ретроспективі.

Виклад основного матеріалу статті. Найважливішими економічними передумовами для формування громадянського суспільства $€$ різноманіття форм власності та соціально орієнтована ринкова економіка.

Фундаментом громадянського суспільства можна вважати приватну власність. Остання, створюючи чимало центрів економічної влади, виключає її централізацію однією особою, групою або партією і врівноважує владу всередині держави. Наявність альтернативних засобів до існування забезпечує свободу вибору в різних сферах суспільного життя. Тому розмежування власності і влади, економічної і політичної свободи можна вважати критерієм реального існування громадянського суспільства.

Економічний індивідуалізм стверджує особисту свободу і приватну власність, разом із тим $€$ одним із теоретичних витоків концепції громадянського суспільства, одним зі стимулів суспільного розвитку і становлення демократії. Особистість не може бути вільною без свободи економічного вибору, який, у свою чергу, передбачає обмеження державного всевладдя в економічній сфрері [11].

Прийняття Декларації про державний суверенітет 16 липня 1990 р., Законів України «Про економічну самостійність», «Про банки і 
банківську діяльність» від 20 березня 1991 р., «Про зовнішньоекономічну діяльність» від 16 квітня 1991 р., встановило основні принципи внутрішньої та зовнішньої сфери економічного життя тогочасного українського суспільства.

Українці мали гарні стартові можливості для розбудови своєї економіки на початку 90-х рр. Після здобуття незалежності перед українською економікою відкривалися широкі перспективи. Адже молода українська держава отримала в спадок від СРСР добре розвинуті металургійну, хімічну промисловість. Україна займала друге місце в СРСР за рівнем промислового та науково-технічного потенціалу.

Першою серйозною проблемою, яка постала перед урядом, стала організація роботи підприємств, які раніше перебували в загальносоюзному підпорядкуванні і мали тісні кооперовані зв'язки із організаціями в інших колишніх союзних республіках. Оптимізм очільників молодої держави наштовхнувся на ряд дестабілізуючих для української економіки фракторів. Йдеться про успадкування майже третини військово-промислового комплексу СРСР, низьку продуктивність сільського господарства. Усе це потребувало вливання величезних державних коштів [6, с. 64-65].

Досить важко було розбудовувати інститути громадянського суспільства з населенням, яке чекало державної опіки, зневажало приватну власність і ринкову економіку. Ускладнювала соціальне становище втрата українцями заощаджень в загальносоюзному Ощадному банку, грошові фронди якого назавжди опинилися в Російській Федерації. СРСР як суб'єкт міжнародного права припинив існування, але система Ощадбанку СРСР існувала. Тому українське республіканське керівництво Ощадбанку наприкінці року здійснило черговий переказ. Але в 1992 р. виявилося, що попри те, що Росія була 
правонаступником СРСР, виконувати свої зобов'язання щодо вкладів Ощадбанку вона відмовляється. Ощадбанк України, створений у 1992 р., всі заощадження, які були на рахунках громадян станом на 1 січня 1992 р. (близько 53 мільйонів) виніс на окремий позабалансовий рахунок, покладаючи їхню долю на український уряд. Але українська влада практично не повернула громадянам їхні заощадження [9].

Дещо стабілізували становище вступ України в 1992 р. до Міжнародного валютного фонду, початок співпраці з Європейським Банком Реконструкції та Розвитку (ЄБРР), Світовим банком та іншими міжнародними установами. Вдалося вивести українську валюту на міжнародний ринок, врегулювати зовнішньоекономічні розрахунки.

На жаль, на початку 1990-х рр. уряд не вдався до політики «шокової терапії», яка продемонструвала свою результативність і в Польщі, і навіть в сусідній Росії. Та провести такий комплекс заходів означало стати політичним камікадзе, піти на непопулярні, однак вкрай важливі для розбудови економіки країни рішення.

Завдяки плану економічних реформ Лешека Бальцеровича протягом 1989-1992 рр. зростання ВВП у Польщі склало 2,6\%, а через три роки зросло до $7 \%$. Але полякам довелося зіткнутися із підвищенням цін на продовольство, обмеженням доходів пересічного громадянина і скороченням видатків із бюджету. Та посткомуністичні проблеми були швидко подолані в Польщі. Польському суспільству вдалося закласти міцний соціально-економічний фрундамент для трансформації його в громадянське [10].

Але курс на радикальні реформи українські уряди 90-х рр. не брали. Єдиний прем'єр-міністр часів Л. Кравчука, котрий відкрито заявляв про необхідність реформ, був Л. Кучма, який очолював уряд 3 жовтня 1992 р. по вересень 1993 р. Тодішній віце-прем'єр В. Пензеник запропонував український варіант «шокової терапії». Суть його 
економічної програми можна звести до кілько їх пунктів: обмеження пільгових кредитів, скорочення субсидій; контроль Національного банку за асигнуваннями; масштабна приватизація; жорстка економія енергоносіїв.

Одним із головних завдань, які ставив перед собою Президент, виведення України із рубльової зони й утвердження нової валюти карбованця. План реформ провалився, а «реформатори» змушені були піти у відставку. Не вдалим виявився курс Л. Кучми на стабілізацію національної валюти (карбованця, а з 1996 р. - гривні). Уряд встановив обов'язковий продаж підприємствами 50\% валютної виручки й адміністрував курс вітчизняної валюти щодо іноземної. Попри очікувані результати, країну охопила в 1993 р. інфляція в $10155 \%$ [19].

Початок 90-х рр. - час появи ще одного вкрай згубного для розбудови громадянського суспільства і держави явища - «тіньової економіки». Запровадження в 1992 р. податку на додану вартість в умовах економічного спаду й дестабілізації видавалося експертам украй сумнівним. На думку фахівців, до 1996 р. близько 60\% операцій відбувалося поза системою оподаткування.

Існування економіки «в тіні» - це серйозна перешкода для формування економічного підгрутня розвитку громадянського суспільства. Адже, цей фрактор унеможливлює розвиток конкурентноздатності, зростання соціальних стандартів. Це своєрідний індикатор криміналізації економічних процесів, корумпованості органів державної влади та низької правової і податкової культури юридичних та фрізичних осіб [19].

Незважаючи на те, що Держкомстат з 2004 по 2010 рр. звітував про рівень тінізації економіки України на рівні 16-19 \%, реальні цифри міжнародними експертами визначаються до від 44 \% до 50 \%. За 
приблизними підрахунками вчених за перші 10 років незалежності 3 України було вивезено щонайменше 40 мрд. доларів. Обсяги тіньової економіки на кінець 1990-х рр. становили близько 60 \% ВВП. Це вкрай негативне явище не тільки з точки зору кримінальності, корумпованості, зростання впливу окремих осіб та груп, а навіть із суто економічних міркувань. По-перше, такий величезний капітал, отриманий незаконним шляхом, не вкладається у розвиток вітчизняної економіки, а приховується у фрінансових установах іноземних країн, стимулюючи до розвитку їхні економічні системи. По-друге, внаслідок вимивання із економіки такого валу, виникає своєрідний вакуум, який заповнюється іноземною валютою. Це серйозний удар по стабільності вітчизняної валюти та її залежності від іноземної [20].

Тіньова економіка сприяє зрощенню влади й бізнесу, фрормуванню паралельної влади в країні. Могутній податковий тиск з боку держави значно обмежує підприємницьку діяльність. А з іншого - спонукає бізнес до просування у органи законодавчої та виконавчої влади представників, які лобіюють їхні інтереси. В такому разі політика перетворюється на фрарс, а за розбудову інститутів громадянського суспільства можна говорити хіба в контексті задоволення інтересів промислово-фрінансових груп [3, с. 693].

Становлення ринкової економіки не відбувається без процесів роздержавлення, приватизації. Приватизацію розпочали в 1992 р. так званою «малою приватизацією». Йшлося про роздержавлення об'єктів в легкій, харчовій, місцевій промисловості. Варто вказати на фрорми приватизації, оскільки завдяки такому шляху більшість населення була усунена від цього процесу. Спочатку підприємства корпоратизувалися, тобто змінювали організаційно-правову фрорму існування - ставали акціонерними товариствами. А потім більшу частину акцій купували їхні директори. 
Після відставки Л.Кучми Президент Л.Кравчук самостійно очолив уряд, об'єднавши свій апарат і Кабінету Міністрів. Виконуючим обов'язки глави уряду було призначено Ю. Звягільського. Та досягнення урядової команди в економічній сфері України в 1993-1994 рр. були досить невиразними. Адміністративними методами вдалося загальмувати ріст інфляції $(2,1 \%)$, ріст цін на споживчі товари $(1,7$ рази проти показника 1,9 в попередньому році) [2].

3 початку 90-х рр. відзначимо ще одну негативну тенденцію постійне втручання держави в макро- та мікроекономічні процеси, спроби постійного адміністрування, впливу, навіть примусу. Це аж ніяк не сприяло побудові ринкових відносин, розвитку конкурентноздатності, сприятливого інвестиційного клімату.

Країні і суспільству не було запропоновано перспективного шляху розвитку. Радикальні реформи були не вигідні впливовим економічним кланам, інтереси яких (а не громадянського суспільства), лобіювали політики.

За врядування Кравчука-Звягільського значно зріс податковий тиск на населення, яке змушене було віддавати від 40 до 90 \% своїх прибутків. Такі дії лише сприяли подальшій тінізації економіки. В 1994 р. фрінансова система країни була майже зруйнована. Рівень ВВП впав порівняно із попереднім роком на $23 \%$, знизилися виробництво промислової (на 27,8 \%) та сільськогосподарської продукції (на 16,5 \%). В умовах фрінансового краху було прийнято рішення про проведення дострокових парламентських і президентських виборів. Хотілося б відзначити, що другого шансу політикам в Україні майже ніколи не давали, «права на помилку» не було. Часта зміна урядів і складу парламенту тільки дестабілізували політичне та економічне життя країни [3, с. 695]. 
Новий Президент Л.Кучма в жовтні 1994 р. проголосив першочерговими завданнями лібералізацію цін і валютного курсу, максимальне сприяння вільній внутрішній і зовнішній торгівлі, подальшу приватизацію за умови суворої монетарної політики та відновлення перерваних економічних зв'язків із Росією. На 1996 р. вдалося досягти певної фрінансової стабільності. Приватизація йшла значними кроками. На кінець 1990-х років питома вага державної власності скоротилася з 96 \% до 40 \% [21, с. 447].

Після проведення грошової реформи 1996 р., унаслідок якої було деноміновано карбованець у 100 тис. разів і введено до обігу нову національну валюту гривню, вдалося стабілізувати вітчизняний фінансовий ринок. Мала позитивний вплив на вітчизняну економіку фінансова допомога від США, ФРН та міжнародних фінансових установ у проведенні економічних рефрорм. Припинилися катастрофрічні темпи падіння ВВП, в 1995 р. рівень його спаду не перевищував попередній рік, а в 1997 - він був вже на рівні 3,2 \%. Та це були лише незначні проблиски на фоні катастрофічних явищ у національній економіці. Йдеться про зовнішні борги країни за енергоносії. Слід зазначити, що в 1991 р. зовнішній борг України становив нуль, адже Російська Федерація взяла на себе фрінансові зобов'язання СРСР [3, с. 696].

Ситуація із ринком енергоносіїв це окрема і дуже важлива сторінка економічного і суспільно-політичного розвитку України, оскільки із самого початку 1990-х і до сьогодні впливає на всі сфері життя. Для цього склалися сприятливі передумови в самій Україні - 35 тис. кілометрів трубопроводів високого тиску і 12 підземних сховищ ємністю 30 мрлд. кубометрів. Через неефективний державний менеджмент вже в 1993 р. країна мала борг перед Росією та Туркменістаном. Саме в цей час до справи взялися посередницькі організації, які за субсидійованою ціною купували газ у постачальників і за завищеною 
продавали Україні, Польщі та іншим країнам. Транспортування оплачували тим же газом, порахувати який було просто фрізично неможливо. Складалася ситуація, коли свій газ продавали дрібним споживачам. А от імпортний, на якому можна було найбільше заробити, великим підприємствам. Безперечно у таких схемах брали участь чиновники найвищого рангу. Так, у квітні 1994 р. уряд В. Масола дав доручення невідомій організації «Республіка» здійснювати бартерні розрахунки за газ із Туркменістаном на суму 651 млн. доларів. Організація невдовзі була на межі банкрутства, а борг погасили (хоч і частково) за рахунок активів банку «Україна» [6, с. 71-73].

За таких умов зростала залежність економіки України від ринків енергоносіїв Росії та Туркменістану, міжнародних фрінансових установ, у яких доводилося позичати кошти для розрахунку за газ і нафрту. Станом на 1999 р. Україна мала зовнішній борг у 12 млрд. доларів. Були величезні борги перед населенням (зарплата, стипендія) у 12 млрд. гривень.

Ситуацію ускладнювала часта зміна урядів та правил гри як для своїх гравців, так і для іноземного бізнесу, який неохоче вкладав кошти у вітчизняну економіку. Протягом 1994-1997 рр. уряд очолювали В. Масол, Є. Марчук, П. Лазаренко, В. Дурдинець, В. Пустовойтенко.

Ситуацію в економіці може продемонструвати рівень ВВП. Якщо в 1990 р. він становив 157,9 млрд. доларів, то в 1998 р. - 40,8 млрд. доларів. В грудні 1999 р. Л. Кучмі довелося визнати некерованість економічних процесів в країні та високий рівень криміналізації і корумпованості різних сфрер економіки. Та попри провал економічних реформ, завдяки вдалим політтехнологіям в 1999 р. країну знову очолив Л. Кучма.

Нова економічна програма Л. Кучми напередодні виборів отримала назву «Україна-2000». Та в умовах припинення зовнішнього 
кредитування необхідно від декларацій було переходити до рішучих дій. У грудні 1999 р. президент видав так званий «аграрний» указ «Про негайні заходи щодо прискорення реформування аграрного сектору економіки». Документ був спрямований на ліквідацію колгоспно-радгоспної системи. До 2000 р. було ліквідовано колгоспи і радгоспи, а 6,5 млн. селян стали власниками 26,5 млн. гектар сільськогосподарських угідь. Держава «пробачила» борг сільськогосподарським підприємствам в розмірі 7 млн. доларів США [22, c.8-9].

Соціальний аспект земельної реформи не був повністю реалізований. Проблема полягала в тому, що сільськогосподарські підприємства нового зразка, які орендували землю в селян, перетворювалися фрактично у колишні колгоспи із надмірною централізацією влади, бюрократією, нехтуванням інтересами селян, затримками виплати за оренду землі чи заміну грошової фформи оплати натуральною.

Мала місце й інша проблема - неконтрольовані відчуження землі в селян за мізерну ціну. Приватні фрірми скуповували землю по 100-200 грн. за гектар за номінальної вартості в 8,5 тис. грн. Відчуження землі набуло таких масштабів, що Верховна Рада України в 2001 р. прийняла закон про заборону будь-яких фрорм відчуження паїв, окрім передачі в спадок. Було встановлено й мінімальну плату за оренду землі - не менш як 1 \% від вартості земельної ділянки.

Все ж такі новели у аграрних відносинах заклали потужну базу для ринкових відносин у сільському господарстві. Поряд 3 такими негативними рисами як концентрація землі в руках колгоспнорадгоспних лендлордів [6, с.155], можна було з упевненістю говорити про підвищення ефективності праці, зниження витрат на виробництво. Та подолати технічну відсталість сільського господарства й залучити 
до нього населення (25 \% в Україні, 5 \% - в ЄС) тоді не вдалося [6, с. 155].

В соціально-економічному житті країни намітилися позитивні зрушення, як в промисловості, так і в сільському господарстві. Завдання, яке постало перед очільниками держави - не розгубити і примножити отримані здобутки. Реалізувати такі цілі доручили В. Ющенку, колишньому Голові Правління Ради Національного Банку України, який очолив уряд з 22 грудня 1999 р. із антикризовою програмою «Реформи заради добробуту». Він отримав можливість самостійно формувати уряд і здійснювати економічні реформи.

Одним із перших кроків нового прем'єр-міністра стала енергетична сорера, де існувало чимало зловживань. Віце-прем'єр міністр Ю. Тимошенко, як ніхто знала які існують незаконні операції в нафртогазовій сфері. Тому було максимально скорочено взаємозаліки та бартерні операції, а тривалих боржників змусили заплатити до державного бюджету. Таким чином, грошові виплати за газ зросли 3 49,2 \% до 87,1%. Це сприяло оздоровленню економіки, збільшення доходів бюджету, зростанню соціальних виплат.

Становлення громадянського суспільства і ринкової економіки, хоч і дуже повільними темпами, засвідчив і розвиток малого підприємництва. У 2000 р. нарешті запрацював указ президента про пільги відносно невеликих підприємців. Станом на 2002 р. 23 \% зайнятого населення були дрібними підприємцями. Це означало збільшення податкових надходжень до бюджету. Вже за врядування В. Януковича було прийнято 30 \% податок на прибуток, один із найнижчих у Європі [6, с. 157].

Таким чином, уряду В. Ющенка вдалося уникнути дефролту, скоротити державний борг на 17 \% (2,8 млрд. доларів), зберегти життєздатність енергетичної системи, встановити жорстку фінансову 
дисципліну, перейти від бартерних операцій до наповнення бюджету реальними грошима. Якщо протягом 1992-1999рр. рівень ВВП скоротився на 60 \%, то за 2000 р. він вперше виріс на $6 \%$, а наприкінці правління В. Ющенка була позитивною динаміка розвитку сільського господарства (6 \%), промислового виробництва $(18,4$ \%) [18, с. $178-$ 179].

Варто відмітити й боротьбу уряду з бюрократичними обмеженнями. В. Ющенко скасував більше 150 нормативно-правових актів, що заважали нормальному розвиткові бізнесу. За погодженням із західними експертами було реорганізовано роботу центральних державних відомств та установ.

Незважаючи на значне пожвавлення економіки, реального зростання добробуту пересічного українця не відбулося. Значну частину сімейного бюджету поглинали їжа, одяг, житлово-комунальні послуги. Доводилося економити на якості життя та відпочинку. Не вдалося створити належні умови для розвитку національного капіталу. Врешті-решт активна діяльність віце-прем'єра Ю. Тимошенко над встановленням державного контролю за приватизацією обленерго наштовхувалася на спротив представників впливових промисловофрінансових кіл, зокрема й Г. Суркіса, що координував діяльність фрракції СДПУ (о) [3, с. 697].

26 квітня 2001 р. Верховна Рада проголосувала за недовіру до Кабінету В. Ющенка. А 29 травня новий уряд очолив прибічник Президента керівник Української спілки промисловців і підприємців А. Кінах, який взяв курс на подальшу стабілізацію української економіки. Так, в 2001 р. ріст ВВП становив 9 \%, а промислового виробництва $14,2 \%$. Але за свідченням експертів урядові в цьому складі не вдалося зберегти позитивну динаміку економічних змін. Так, в 2002 р. темпи зростання ВВП знизилися до 4,3 \%. За перше півріччя 2002 р. 
зменшилося виробництво 66 із 150 найважливіших видів промислової продукції. Майже на 15 \% впали доходи населення. За даними експертів в 2002 р. близько половини іноземних інвестицій повернулося до країн-інвесторів, за півроку бюджет вдалося наповнити лише на $44 \%$ [23].

Вище перераховані фрактори стали вирішальними, щоб відправити 16 листопада 2002 р. уряд А. Кінаха у відставку. Новим прем'єрміністром став В.Янукович. Значну роль в діяльності Кабміну відігравав віце-прем'єр М. Азаров. Слід відзначити позитивні зрушення в економіці. Темпи зростання ВВП були чи не найбільшими в Європі. Прибутки населення зросли в 2004 р. на 19,7 \%, заробітна плата - на $42 \%$, мінімальні пенсії - на 55,5 \%. 31 січня прогресивне оподаткування було замінено єдиним податком в $13 \%$.

Продовжувала приватизація державного майна. Лише за кілька місяців 2004 р. Фонд держмайна передав до державного бюджету 8,24 млрд. грн. Приватизаційні процеси, а точніше «велика приватизація» поліпшила інвестиційний клімат. Вдалося подолати безробіття, відновити експортний потенціал, особливо втрачені позиції в металургійній та хімічній промисловості. Бюджет виріс більш ніж в чотири рази за рахунок надходження ПДВ, митних зборів, акцизних платежів.

Але в 2004 р. можна спостерігати і негативні економічні явища. Інфляція зросла до 9 \%, борги уряду перед бюджетниками склали 1,2 млрд. грн. Досить негативно позначилася на політичному іміджеві В. Януковича «бензинова криза» літа 2004 р., яка спровокувала зростання цін на усі товари. Зокрема, на 50 \% подорожчало пальне, на 26 \% м'ясо та ковбасні вироби. Нове житло зросло у ціні на 20 \%. Уряд намагався адміністративними методами врегулювати ситуацію. Дотувалися неприбуткові сфери народного господарства, 
встановлювалися фіксовані верхні ціни на продукти народного споживання, зокрема хліб. Але такі заходи привели до невдоволення політикою уряду підприємцями і до зростання національного боргу. Та навіть за такої ситуації прибутки громадян чи не вперше за всю історію незалежної України перевищили рівень інфляції.

Після перемоги «помаранчевої революції» органи державної влади в черговий раз були перерозподілені. Політична боротьба і переділ «портфелів» знову були в епіцентрі життя українського суспільства. Досить неоднозначними було соціально-економічні здобутки «помаранчевої влади». Урядові вдалося покінчити із численними махінаціями щодо повернення ПДВ державою. Внаслідок чого в 2005 р. надходження від ПДВ зросли вдвічі [16, с. 5].

Програма Ю. Тимошенко «Контрабанда - стоп!» дозволила зменшити зловживання на кордонах та реально збільшити митні надходження. Було ліквідовано запроваджене ще Л. Кучмою правило обов'язкового продажу 50 \% валютної виручки українськими підприємствами, що дозволило знизити рівень приховування валюти від податкових органів. Вдалося знизити імпортне мито на $90 \%$ імпортних товарів. Розпочато роботи по спрощенню реєстрації приватних форм та підприємств.

Але значним ударом по електорату Ю. Тимошенко стали ї̈ ініціативи з оподаткуванням малого бізнесу, які загрожували його подальшим виходом у «тінь». Незважаючи на те, що малому підприємництву дали спокій, недовіра до Кабінету Міністрів у підприємців залишилася. В 2005 р. уряд Ю. Тимошенко було відправлено у відставку. За 8 місяців врядування вдалося «досягти» падіння вітчизняної економіки в 2,5 рази, заборгованість по компенсації ПДВ досягла 2,6 млрд. грн., а притік іноземних інвестицій скоротився на $14 \%$. 
Вже після відставки уряду Ю. Тимошенко відбувся аукціонперепродаж «Криворіжсталі» індійській компанії «Міттал Стіл» за 5 млрд. доларів, суму в 6 разів вищу, чим було сплачено державі попередніми покупцями [12]. Для покриття наслідків неефективного управління використовувалися державні позики. За даними Міністерства фрінансів у період діяльності уряду Ю. Тимошенко з грудня 2007 по лютий 2010 р. зовнішній борг країни сягнув 316 млрд. грн. $35 \%$ ВВП.

Неоднозначно була сприйнята спроба тиску на спеціальні економічні зони і території пріоритетного розвитку для підйому економіки менш розвинених регіонів і для економічного експерименту із залученням іноземних інвестицій. Податкові пільги були скасовані і для фрірм, які працювали за корупційними схемами і для тих підприємців, які дійсно робили значний внесок у розвиток економіки. Після ліквідації спеціальних економічних зон виявилося, що 65 \% проектів були дійсно вигідні. А такі кроки привели до зниження довіри інвесторів [5, с. 6].

Варто згадати і про ревальвацію гривні. Навесні 2005 р. гривня без попередження здорожчала на 25-30 коп., Нацбанк встановив курс відносно американського долару 5,05 грн. Це вдарило і по експортним операціям і знецінило валютні заощадження громадян.

Навесні 2005 р. знову спалахнула паливна криза. Уряд пояснював іiї змовою нафтотрейдерів російський компаній ТНК і Лукойл. Були залучені Антимонопольний комітет, СБУ, використовувалися економічні заходи у вигляді закупівлі нафртопродуктів у закордонних нафртотрейдерів. Склалися умови для супротиву монополістам, а ринок України зробити конкурентнішим і відкритішим. Але президент В. Ющенко втрутився у ситуацію, створив незалежну комісію і вибачився перед монополістами, яких «образили». 
До такої складної ситуації в економіці долучилися внутрішньополітичні чвари між помаранчевими коаліціянтами та взаємні звинувачення у шахрайстві та розкраданні державних коштів. Врешті решт В. Ющенко 8 вересня сенсаційно відправив у відставку Ю. Тимошенко, П. Порошенка (голову РНБО), О. Третьякова (свого першого помічника) та прийняв відставку О. Зінченка (голови секретаріату президента).

Після позачергових парламентських виборів 2007 р. 18 грудня розпочалося друге урядування «леді Ю». Та проходило воно за досить несприятливих обставин. Окрім кризи політичної, з осені 2008 р. Україна потрапила у вир світової економічної.

Все ж варто наголосити на здобутках уряду Ю. Тимошенко. Протягом першої половини 2008 р. доходи населення підвищувалися, грамотно відбувалося розпоряджання бюджетними коштами. Так, за період січень-лютий зарплата зросла на 4 \%, соціальні допомоги й інші виплати - на 48 \%. ВВП у вересні 2008 р. мав позитивну динаміку в 6,7 \%. Було підвищено соціальну допомогу при народженні дитини, поступово виплачувалися ощадбанківські вклади. Україна стала повноправним членом СОТ [14].

Але ці активи уряду Ю. Тимошенко затьмарювалися значним рівнем інфрляції. Лише за перші 4 місяці 2008 р. ціни зросли на 13,7 \%. Безумовно це знижувало ефективність соціальних ініціатив уряду.

Наслідком світових макроекономічних коливань стало тотальне знецінення вітчизняної валюти. В 2009 р. ВВП мав негативну динаміку 20,3 \%. порівняно із 2008 р. Ситуацію вдалося стабілізувати навесні 2009 р. Знизилися темпи падіння ВВП, темпи інфляції. Стабілізувався валютний ринок, МВФ продовжив програму кредитування. Та це були останні подихи держави, яку роздирали політичні чвари. Президент був позбавлений впливу на ситуацію. 
Користуючись, політичною та економічною нестабільністю в Україні, Росія в січні 2009 р. розгорнула газову війну проти України. Окрім інформаційних атак і пропагування в країнах ЄС України як ненадійного партнера по постачанню газу, російський «Газпром» посеред зими припинив постачання газу. Метою таких дій було звичайно підняти ціну на російський газ. До «газової війни» 2008-2009 рр. ціна на газ була $235 \$$ за 1 тис. куб. метрів. Спроби В. Ющенка врегулювати конфрлікт закінчилися невдачею, 18 січня 2009 р. прем'єрміністри Росії та України домовилися між собою про нові умови газової співпраці. Відтепер ціна на газ стала «європейською» - 450\$ за 1 тис. куб. метрів. В. Ющенко назвав угоду неприйнятною для України, він висловився за ії оптимізацію або скасування, але його вже ніхто не сприймав як рішучого політика [8].

Висновки. Таким чином, проаналізувавши соціально-економічні передумови становлення громадянського суспільства, варто наголосити на такому. Особливості соціально-економічного розвитку України не пришвидшили, а навпаки уповільнили розбудову інститутів громадянського суспільства. До них варто віднести: нерішучість українського політикуму щодо ресоорування української економіки на початку 90-х рр., коли Україна була фрактично «чистою дошкою»; домінування політики над економікою, політичного іміджу над вирішенням нагальних питань; непродумана податкова політика спричинила появу «тіньової економіки», яка за різними підрахунками становила 50-60\% ВВП України; поява державного боргу перед міжнародними фрінустановами (на 1999 р. - 12 мрлд. грн.); корупційні дії тодішньої влади призвели до залежності України від іноземних енергоносіїв; економічний тиск на підприємців призвів до зростання політики і бізнесу, який змушений був захищати свої інтереси. Політики почали працювати не громадян, а на промислово-фрінансові клани; 
прагнення урядів «залатати» економічні прорахунки державними (фактично нашими) коштами.

Тому навіть по спливу 25 річниці незалежності, у сучасній Україні недостатньо розвинені як ринковий соціалізм, так і соціально зорієнтована економіка. В цих умовах реалізація соціальних функцій сучасної української держави за її економічної неспроможності зберігає домінуючу роль держави в забезпеченні соціальних гарантій, які здебільшого мають характер, властивий для колишньої соціалістичної держави, веде до обмеження абсолютних прав власника, посилює втручання держави в життя людини, громадянського суспільства та його інститутів.

Історія економічного розвитку незалежної України - це історія боротьби окремих промислово-фінансвоих груп за сфери впливу. В результаті цієї боротьби значна частина національної власності була вилучена із обороту і потрапила у приватні руки. Ще одним наслідком цієї боротьби стала цілковита залежність законодавчого органу від інтересів цих груп.

В Україні склався особливий тип економіки, своєрідний державний капіталізм. 3 одного боку, присутні елементи ринкової економіки, 3 іншого боку, успішним учасником такої економіки $€$ загравання із державним бюрократичним апаратом. Тому виникли серйозні деформації і у структурах влади і в політичній організації суспільства. Економічна та політична влада зосередилися в руках невеликої групи людей - олігархії, почала розвиватися паралельна економіка, заснована на корупції. Це стало серйозним гальмом для розбудови інститутів громадянського суспільства.

\section{תimepamypa:}


1. Барков В.Ю. Сучасні проблеми формування громадянського суспільства в Україні // Відносини між державою і громадянським суспільством: Матеріали «круглого столу». - К., 2003. - С.51-56.

2. Бойко О. Д. Історія України: Посібник / О. Д. Бойко. - К.: Видавничий центр «Академія», 2002. - 656 с.

3. Воронянський О. В. Економічна політика держави в сучасній Україні: короткий огляд / О. В. Воронянський // Гілея. - Київ: - 2012. - Вип. 59. - (№4). - C. 692-697.

4. Головащенко О. С. Становлення громадянського суспільства як соціальної основи правової держави / О. С. Головащенко // Форум права. - 2012. - №4. - С.219-222.

5. Дацишин М. Постреволюційний уряд і сезонні граблі / М. Дацишин // Національна безпека і оборона. - 2005. - № 9. - С. 6.

6. Касьянов Г. Україна 1991-2007: нариси новітньої історії / Г. Касьянов - К.: Наш час, 2007. - 432 c.

7. Колодій А.Ф. На шляху до громадянського суспільства. Теоретичні засади й соціокультурні передумови демократичної трансформації в Україні. Монографрія. - Львів: Видавництво «Червона Калина». - 2002. $-276 c$.

8. Кушнірук Б. Газова війна - 2009: чи міг Путін шантажувати Тимошенко? / Б. Кушнірук. - [Електронний ресурс]. Режим доступу: http://www.unian.ua/politics/502546-gazova-viyna-2009-chi-mig-putinshantajuvati-timoshenko.html.

9. Кушнірук Б. Знецінені заощадження: історія держави, якої вже нема, або трагедія пересічних громадян України / Б. Кушнірук // Українська правда. Блоги. - 21 серпня 2007 р. [Електронний ресурс]. Режим доступу: http://www.unian.net/ukr/news/news-225738.html.

10. Листровий А. Чи потрібен Україні Бальцерович та його шокова «терапія» / А. Листровий // Козацький журнал Сурма. - 23 квітня 
2016 p. [Електронний ресурс]. Режим доступу: https://surmasite.wordpress.com/2016/04/23/чи-потрібен-українібальцерович-та-йо.

11. Макарова I. В. Розвиток інститутів громадянського суспільства: історичні аспекти / I. В. Макарова. - [Електронний ресурс]. Режим доступу: http://www.dridu.dp.ua/zbirnik/2010-01/10mivsia.pdf.

12. Маскалевич І. «Криворіжсталь»: десять років однієї години / I. Маскалевич // Дзеркало тижня. - 2005. - 29 жовтня -4 листопада.

13. Нечипоренко О.М. До проблеми шляхів та форм творення громадянського суспільства // Науковий вісник ДЮІ МВС України. 2001. - №3 (6). - C.269-276.

14. Парфььонова Г. Якою має бути Україна або громадянське суспільство, як формула успіху громади і країни / Г. Парфьонова // http://www.hgi.org.ua/detal_proekty.htm.

15. Розова Т. В., Барков В. Ю. Специфика становления гражданского общества в Украине: Монографрия. Одесса: Юрид. Литература, 2003. $-336 c$.

16. Рік діяльності нової влади. Погляд неурядових аналітичних центрів // Національна безпека і оборона. - 2005. - №12. - С.5.

17. Рудич Ф. Громадянське суспільство в Україні: віражі і перспективи сходження // Віче. - 2004. - №6 (147). - С.39-44

18. Тележурналісти протестують проти утисків [без авт.] // Електронне видання BВC.Ukrainian.com. - 28 жовтня 2004 р. Режим доступу:

http://www.bbc.com/ukrainian/domestic/story/2004/10/041028_1plu1_prote sts.shtml.

19. Тіньова економіка в Україні: причини та шляхи подолання [Ангела Бочі, Василь Поворозник]. Офріційний сайт Міжнародного центру 
перспективних досліджень. Електронний ресурс. Режим доступу: http://icps.com.ua/assets/uploads/files/t_novaekonom_kaukra_ni.pdf.

20. Тіньова економіка в Україні: маситаби та напрями подолання: аналіт. доп. / [Т. А. Тищук, Ю. М. Харазішвілі, О. В. Іванов]; за заг. ред. Я. А. Жаліла. - К. : НІСД, 2011. - 96 с.

21. Українська приватизація у спогадах та роздумах / Aвт.уклад. В. С. Ларцев, Г. Н. Ключиков . - Київ: Поліграф-Інформ: Велес, 2001. -479 c.

22. Як голосують селяни? Забезпечення усвідомленого вибору [Текст] / С. А. Горобчишина [та ін.]. - К.: Укр. незалеж. центр політ. досліджень, 2005. - 124 c.

23. Як розвивається український Інтернет та еволюціонує аудиторія (статистика GFK) [Електронний ресурс] - Режим доступу: http://blogosphere.com.ua/2011/11/22/ukrainian-internet-and-socialnetworks/.

\section{References:}

1. Barkov V. Yu. Modern problems of civil society formation in Ukraine // Relations between the state and civil society: Materials of the "round table". - K., 2003. - p.51-56.

2. Boyko O. D. History of Ukraine: A Manual / O. D. Boyko. - K.: Publishing Center "Academy", 2002. - 656 pp.

3. Voronyansky O. V. The Economic Policy of the State in Contemporary Ukraine: A Brief Review / O. V. Voronyansky // Gilea. - Kyiv: - 2012. - Vip. 59. - (No. 4). - P. 692-697.

4. Golovashchenko O. S. Formation of civil society as a social basis of the rule of law / O. S. Golovashchenko // Forum is right. - 2012. - No. 4. P.219-222.

5. Datsishin M. The post-revolutionary government and seasonal rake / $M$. Datsishin // National Security and Defense. - 2005. - No. 9. - P. 6. 
6. Kasyanov G. Ukraine 1991-2007: Essays on Contemporary History / G. Kasyanov - K.: Our Time, 2007. - 432 p.

7. Kolodiy A. F. On the way to civil society. Theoretical foundations and socio-cultural preconditions of democratic transformation in Ukraine. Monograph. - Lviv: Publishing House "Chervona Kalina". - 2002. - 276 p.

8. Kushniruk B. Gas war - 2009: could Putin blackmail Tymoshenko? / B. Kushniruk. - [Electronic resource]. Access mode: http://www.unian.ua/politics/502546-gazova-viyna-2009-chi-mig-putinshantajuvati-timoshenko.html.

9. Kushniruk B. The depreciated savings: the history of the state, which is already missing, or the tragedy of ordinary citizens of Ukraine / $B$. Kushniruk // Ukrainian Pravda. Blogs - August 21, 2007 [Electronic resource]. Access mode: http://www. unian.net/ukr/news/news-225738.html. 10. Listerov A. Does Ukraine need Baltserovich and his shock "therapy" / A. Lisstrov // Kozatsky magazine Surma. - April 23, 2016 [Electronic resource]. Access mode: https://surmasite.wordpress.com/2016/04/23/y-tools-UkraineBaltserovich-ta-yo.

11. Makarova I. V. Development of Civil Society Institutions: Historical Aspects / I. V. Makarov. - [Electronic resource]. Mode of access: http://www.dridu.dp.ua/zbirnik/2010-01/10mivsia.pdf.

12. Maskalevich I. "Kryvorizhstal": ten years of one hour / I. Maskalevich // Dzerkalo Tyzhnya. - 2005 - 29 October - 4 November.

13. Nechiporenko O. M. The problem of ways and forms of civil society creation // Scientific Bulletin of the Ministry of Internal Affairs of Ukraine. 2001. - No. 3 (6). - p. 269-276.

14. Parfenova G. What should be Ukraine or civil society, as a formula for the success of the community and the country / G. Parfenov // http://www.hgi.org.ua/detal_proekty.htm. 
15. Rozova T. V., Barkov V. Yu. Specificity of Civil Society Development in Ukraine: Monograph. Odessa: Yurid. Literature, 2003. - 336 pp.

16. Year of activity of the new government. The View of Non-Governmental Analytical Centers // National Security and Defense. - 2005. - №12. - P.5.

17. Rudich F. Civil Society in Ukraine: Circles and Perspectives of Ascension // Veche. - 2004 - No. 6 (147). - P. 39-44

18. TV journalists protest against harassment [no autos] // Electronic publication BBC.Ukrainian.com. - October 28, 2004 Access mode: http://www.bbc.com/ukrainian/domestic/story/2004/10/041028_1plu1_prote sts.shtml.

19. Shadow economy in Ukraine: causes and ways to overcome [Angela Bocchi, Vasyl Povoroznyk]. The official website of the International Center for Policy Studies. Electronic resource. Access mode: http://icps.com.ua/assets/uploads/files/t_novaekonom_kaukra_ni.pdf.

20. Shadow economy in Ukraine: scales and directions of overcoming: analyst. add / [T. A. Tishchuk, Yu. M. Kharazishvili, O. V. Ivanov]; per community Ed. Ya A. Zhalila. - K.: NISS, 2011. - 96 p.

21. Ukrainian privatization in memoirs and reflections / Auto-style. V. S. Lartsev, G. N. Klyuchikov. - Kyiv: Polygraph-Inform: Veles, 2001. - 479 p.

22. How do the peasants vote? Ensuring a conscious choice [Text] / S. A. Gorobchyshina [and others]. - K.: Ukr. independent. center flight. research, 2005. - $124 p$.

23. How Ukrainian Internet evolves and the audience evolves (GFK statistics) [Electronic resource] - Access mode: http://blogosphere.com.ua/2011/11/22/ukrainian-internet-and-socialnetworks/. 